\title{
BULK DENSITY AND RELATIONSHIP AIR/WATER OF HORTICULTURAL SUBSTRATE
}

\author{
Carolina Fernandes; José Eduardo Corá* \\ UNESP/FCAV - Depto. de Solos e Adubos, Via de Acesso Prof. Paulo Donato Castellane, s/n - 14884-900 - \\ Jaboticabal, SP - Brasil. \\ *Corresponding author <cora@fcav.unesp.br>
}

\begin{abstract}
Change on substrate bulk density during the growing period may negatively affect other substrate physical properties and, consequently, plant growth. The objectives of this research were 1) to characterize physical properties of two horticultural substrates $\left(S_{1}\right.$ and $\left.\left.S_{2}\right), 2\right)$ to evaluate the effect of different bulk densities values of those substrates on their air/water relationship, and 3) to develop mathematical functions to estimate the air/water relationship by increasing substrates bulk density value. First, the distribution of particles size, the bulk density, and the water release curve of the substrates were determined. Then, substrates were packed with three different bulk density values, i.e. $10 \%\left(D_{1}\right), 20 \%\left(D_{2}\right)$ and $30 \%\left(D_{3}\right)$, higher than the bulk density (D) determined in the characterization phase. The water release curves were determined for each bulk density value of both substrates. The effect of increasing substrate bulk density in the total porosity (TP), aeration space (AS), available water (AW), easily available water (EAW), buffering water (BW), and in the remaining water (RW) was evaluated using simple linear regression and polynomial analysis. The particles size distribution and the water release curves were significantly different for the two substrates. Increasing the bulk density value decreased TP and AS, and increased BW and RW. The highest values of AW and EAW were observed for $\mathrm{D}_{1}$. Regression equations obtained can be used to choose the more appropriate air/water relationship for each growing condition.
\end{abstract}

Key words: particle size distribution, substrate bulk density, water release curve, regression equation

\section{DENSIDADE E RELAÇÃO AR/ÁGUA DE SUBSTRATOS HORTÍCOLAS}

\begin{abstract}
RESUMO: Alterações na densidade do substrato durante o cultivo das plantas modificam suas propriedades físicas. O trabalho teve como objetivos caracterizar fisicamente dois substratos hortícolas e avaliar o efeito da densidade na relação ar/água dos mesmos, elaborando funções matemáticas que permitam estimar tal relação a partir da densidade do substrato. Para tanto, determinou-se a distribuição do tamanho das partículas, a densidade e a curva de retenção de água. Procedeu-se o acondicionamento dos substratos em três valores de densidade: 10 $\left(D_{1}\right), 20\left(D_{2}\right)$ e $30 \%\left(D_{3}\right)$ maior que a densidade (D) determinada na fase de caracterização. Partindo das amostras com diferentes densidades, determinou-se a curva de retenção de água dos substratos. A influência do aumento da densidade do substrato na porosidade total (PT), no espaço de aeração (EA), na água disponível (AD), na água facilmente disponível (AFD), na água tamponante (AT) e na água remanescente (AR) foi avaliada pela análise de regressão linear simples e análise polinomial. A composição granulométrica e a curva de retenção de água foram significativamente diferentes para os dois substratos. O aumento da densidade diminuiu a PT e o EA e aumentou a AT e AR. Os maiores valores de AD e AFD foram observados para $\mathrm{D}_{1}$. Foram obtidas equações de regressão que podem auxiliar na escolha da relação ar/água mais adequada para cada condição.

Palavras-chave: composição granulométrica, densidade, curva de retenção de água, equações de regressão
\end{abstract}

\section{INTRODUCTION}

Horticultural production is mainly based on the use of substrate instead of the soil. The substrate, a medium in which roots can grow, also serves as physical support for plants. It can be constituted of pure materials or mixtures. An adequate substrate for plant growing must present high water retension capacity, fast water drainage, and appropriate aeration (Ansorena, 1994). These characteristics are directly influenced by the substrate's particle size distribution and bulk density (Verdonck \& Gabriëls, 1988; Ansorena, 1994; Kämpf, 2000).

The particle size distribution is important to describe the physical quality of the material and its suitableness for plant growth. It influences the volume of air and water held by the substrate. The particle size distribution of the materials used as substrate can vary depending on their origin and grinding conditions, among other factors (Ansorena, 1994). 
Adequate measurements of bulk density are essential to calculate and understand other important substrate attributes for plant growth, such as total porosity, aeration space and available water. The substrate bulk density also influences the water release curve. The determination of the water release curve is important because it yields data on available water to the plants at certain tensions (De Boodt \& Verdonck, 1972). In addition, the recommendation on amount of fertilizers for plant growth always refers to a volume, and demands substrate bulk density value as a reference (Günther, 1983).

At the moment of filling the container with the substrate, the relationship mass of the substrate/filled volume can vary according to the container shape and the applied force. Consequently, other substrate physical properties can also be altered. The substrate bulk density may be affected not only during the process of filling the container but also during some activities carried out in the greenhouses. For instance, to transport the container already filled out, to press the root system during the transplant, and the irrigation practices (Kämpf et al., 1999). The irrigation may compact the substrate, reducing the available water and aeration below critical levels for optimum plant growth. Substrate with low total porosity and low volume of easily available water demand great care on the irrigation management to avoid plant injuries (Fonteno et al., 1981).

Despite the relevance of this subject, little is known about substrate physical properties changes induced by bulk density changes, and the effects of these changes during the plant growth period. Therefore, the objectives of this work were to characterize physical properties of two horticultural substrates $\left(\mathrm{S}_{1}\right.$ and $\mathrm{S}_{2}$ ), to evaluate the effect of different bulk densities values of substrates on their air/water relationship, and to develop mathematical functions to estimate the air/water relationship by increasing substrate bulk density value.

\section{MATERIAL AND METHODS}

Substrates used in this work are recommended for vegetables seedlings, and were basically composed by different amounts of pines peel, peat, expanded vermiculite and ground coal. Two commercial substrate $\left(\mathrm{S}_{1}\right.$ and $\mathrm{S}_{2}$ ) were characterized by determining the particle size distribution, using 4.0, 2.0, 1.0, 0.5, 0.25, and $0.125 \mathrm{~mm}$ sieves; the bulk density (D), following the method described by Hoffmann (1970) quoted by Bellé (1990); and the water release curve (De Boodt \& Verdonck, 1972), all in three replications.

To obtain the bulk density values of $10 \%\left(D_{1}\right)$, $20 \%\left(D_{2}\right)$, and 30\% $\left(D_{3}\right)$ higher than the bulk density (D) determined in the characterization phase, the mass of each substrate was increased by $10 \%, 20 \%$ and $30 \%$. The different amounts of substrates were then used to fill the cores with the same volume. Samples with different bulk densities $\left(\mathrm{D}, \mathrm{D}_{1}, \mathrm{D}_{2}\right.$, and $\left.\mathrm{D}_{3}\right)$ were used to determine the total porosity (volume water content at saturated condition), aeration space (volume water content from 0 to 0.001 Mpa matric potencial), available water (volume water content from -0.001 to -0.01 Mpa matric potential), easily available water (volume water content from -0.001 to -0.005 Mpa matric potential), buffering water (volume water content from -0.005 to -0.01 Mpa matric potential), and remaining water (volume water content at $-0.01 \mathrm{Mpa}$ matric potential), according to De Boodt \& Verdonck (1972).

Particle size distribution and volume water content (\%) at different matric potentials of the two substrates were evaluated using analysis of variance for a completely randomized design with three replications. The means for particle size and volume water content were tested using the Tukey test $(\alpha=0.05)$. Simple linear regression and polynomial analysis (at 0.05 probability level) were used to model the effects of the bulk density on the total porosity (TP), aeration space (AS), available water (AW), easily water available (EAW), buffering water (BW), and remaining water (RW).

\section{RESULTS AND DISCUSSION}

The particle size distribution of the two substrate was significantly different for all size classes except for the $1.00-2.00 \mathrm{~mm}$, in which the two substrates had the same value (20\%). The substrate $\mathrm{S}_{1}$ had larger amount of particles in the $0.25-0.50,2.00-4.00$, and $>4.00 \mathrm{~mm}$ classes. The substrate $\mathrm{S}_{2}$ had larger amount of particles in the $<0.125,0.125-0.25$, and $0.50-1.00 \mathrm{~mm}$ classes (Figure 1).

Substrates with particles well distributed into many size classes, as observed at the present work, may have settlement of the particles during the handling and/ or even during the growth period. The smaller particles may move into the spaces among the larger particles. As a consequence, the total porosity and the aeration space

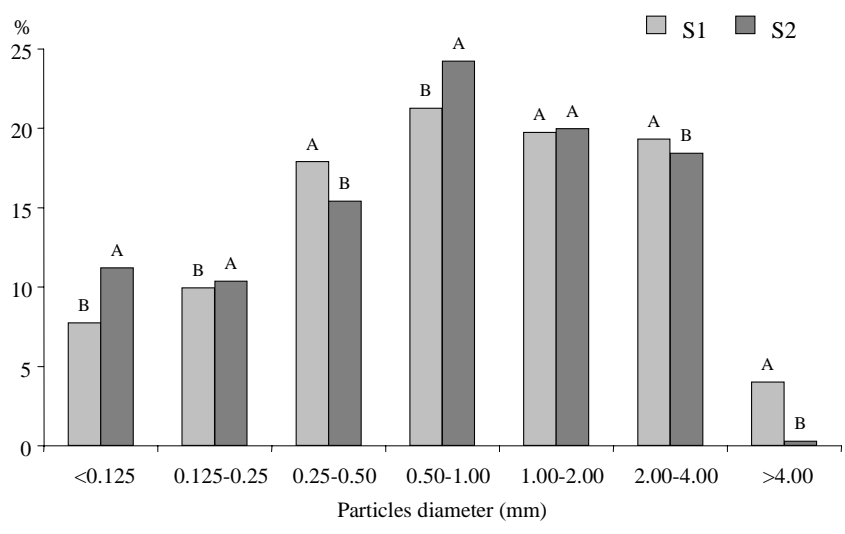

Figure 1 - Particle size distribution for the $S_{1}$ and $S_{2}$ substrate. 
of the substrate will be reduced (Spomer, 1979). On the other hand, the volume of water held by the substrate may increase as a result of the increment of the number of small pores (Ansorena, 1994).

The mean values of bulk density were $320.1 \mathrm{~g} \mathrm{~L}^{-1}$ for the substrate $S_{1}$, and $309.3 \mathrm{~g} \mathrm{~L}^{-1}$ for the substrate $\mathrm{S}_{2}$. Bulk densities values between 100 and $300 \mathrm{~g} \mathrm{~L}^{-1}$ are considered acceptable for seedlings propagation (Kämpf, 2000). Even though substrates used in this work showed a slight higher bulk density, they could be used in seedling propagation.

The two substrates showed different water release curves. The substrate $\mathrm{S}_{2}$ had higher volume water content (\%) up to -0.004MPa matric potential, while the substrate $\mathrm{S}_{1}$ showed higher volume water content (\%) from this point to $-0.01 \mathrm{MPa}$ (Figure 2), probably because of differences between the particle size distribution of the substrates, mainly those associated with the amount of particles in the 0.25-0.50, and 0.50-1.00 mm classes. According to Handreck (1983), quoted by Ansorena (1994), the more important class influencing the aeration porosity and water retention is the $>0.50 \mathrm{~mm}$ class.

The two substrates had TP, AS, EAW, and BW value close to the range suggested as ideal by De Boodt \& Verdonck (1972), when the bulk density value (D) obtained in the characterization phase (Table 1) was considered. However, these ideals values are mean values suggested by the authors, who neither take into account the plant specie nor the growth techniques. Therefore, different values of those mentioned by De Boodt \& Verdonck (1972) may also be considerad adequate.

In general, increasing the bulk density value, decreased TP and AS and increased BW and RW (Table 2). These results may be associated with the increase of the substrate mass that may have occupied part of the pore space that was filled out with air, changing the pore size distribution. The highest value of AW and EAW was observed in the bulk density values of $D_{1}$ and $D_{2}$ for the sub- strate $\mathrm{S}_{1}$, and in $\mathrm{D}_{1}$ for the substrate $\mathrm{S}_{2}$. Because of the increase of the substrate mass, the particles occupied the air space, being the cause of the reduction of the total porosity, and the pore size distribution changed. Probably, the small particles have occupied the void space among the large particles, transforming large pores into small ones, which increased the water hold capacity of the substrates (Spomer, 1979; Ansorena, 1994). The distribution of the substrates particles in several size classes facilitated the adjustment (Figure 1).

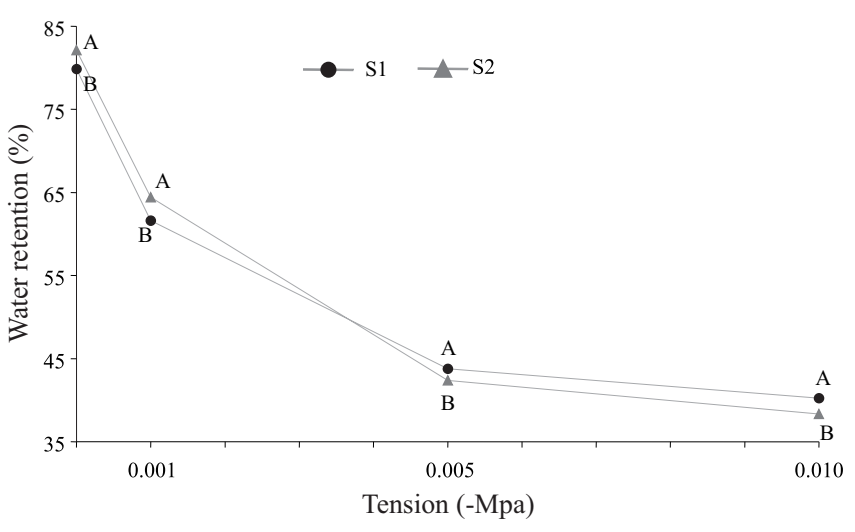

Figura 2 - Water release curves for the $S_{1}$ e $S_{2}$ substrate, in the bulk density D.

Table 1 - Total porosity (TP), aeration space (AS), easily available water (EAW), and buffering water (BW) of the $\mathrm{S}_{1}, \mathrm{~S}_{2}$ and Ideal Substrate (De Boodt \& Verdonck, 1972).

\begin{tabular}{lrrr}
\hline Physical properties & $\mathrm{S}_{1}$ & $\mathrm{~S}_{2}$ & \multicolumn{1}{c}{ Ideal } \\
\hline & ---------- & $\%$ & ----------- \\
Total porosity (TP) & 79.8 & 82.1 & \pm 85 \\
Aeration space (AS) & 18.2 & 17.7 & $20-30$ \\
Easily available water (EAW) & 17.8 & 22.0 & $20-30$ \\
Buffering water (BW) & 3.6 & 4.0 & $4-10$ \\
\hline
\end{tabular}

Table 2 - Total porosity (TP), aeration space (AS), easily available water (EAW), buffering water (BW), and remaining water (RW) in function of the bulk densities values $\left(D, D_{1}, D_{2}\right.$, and $D_{3}$ ) of the substrate $S_{1}$ and $S_{2}$.

\begin{tabular}{lrrrrrrrr}
\hline & \multicolumn{2}{c}{$\mathrm{D}$} & \multicolumn{2}{c}{$\mathrm{D}_{1}$} & \multicolumn{2}{c}{$\mathrm{D}_{2}$} & $\mathrm{D}_{3}$ \\
\cline { 2 - 10 } & \multicolumn{1}{c}{$\mathrm{S}_{1}$} & \multicolumn{1}{c}{$\mathrm{S}_{2}$} & \multicolumn{1}{c}{$\mathrm{S}_{1}$} & \multicolumn{1}{c}{$\mathrm{S}_{2}$} & $\mathrm{~S}_{1}$ & \multicolumn{1}{c}{$\mathrm{S}_{2}$} & $\mathrm{~S}_{1}$ & \multicolumn{1}{c}{$\mathrm{S}_{2}$} \\
\hline $\mathrm{TP}$ & $79.8 \mathrm{Ba}$ & $82.1 \mathrm{Aa}$ & $76.6 \mathrm{Bb}$ & $80.6 \mathrm{Aa}$ & $76.1 \mathrm{Bb}$ & $78.4 \mathrm{Ab}$ & $75.5 \mathrm{Bb}$ & $77.8 \mathrm{Ab}$ \\
$\mathrm{AS}$ & $18.2 \mathrm{Aa}$ & $17.7 \mathrm{Aa}$ & $7.8 \mathrm{Ab}$ & $7.8 \mathrm{Ab}$ & $3.3 \mathrm{Bc}$ & $6.0 \mathrm{Ab}$ & $3.4 \mathrm{Ac}$ & $3.6 \mathrm{Ac}$ \\
$\mathrm{AW}$ & $21.4 \mathrm{Bb}$ & $26.1 \mathrm{Ab}$ & $24.6 \mathrm{Ba}$ & $30.8 \mathrm{Aa}$ & $24.4 \mathrm{Ba}$ & $27.3 \mathrm{Ab}$ & $20.8 \mathrm{Bb}$ & $26.0 \mathrm{Ab}$ \\
$\mathrm{EAW}$ & $17.8 \mathrm{Bb}$ & $22.0 \mathrm{Ab}$ & $20.8 \mathrm{Ba}$ & $25.9 \mathrm{Aa}$ & $20.2 \mathrm{Aa}$ & $22.2 \mathrm{Ab}$ & $16.6 \mathrm{Bb}$ & $20.4 \mathrm{Ab}$ \\
BW & $3.6 \mathrm{Bd}$ & $4.0 \mathrm{Ad}$ & $3.8 \mathrm{Bc}$ & $4.8 \mathrm{Ac}$ & $4.2 \mathrm{Bb}$ & $5.2 \mathrm{Ab}$ & $4.3 \mathrm{Ba}$ & $5.6 \mathrm{Aa}$ \\
$\mathrm{RW}$ & $40.2 \mathrm{Ad}$ & $38.4 \mathrm{Bd}$ & $44.1 \mathrm{Ac}$ & $42.0 \mathrm{Bc}$ & $48.4 \mathrm{Ab}$ & $45.0 \mathrm{Bb}$ & $51.3 \mathrm{Aa}$ & $48.2 \mathrm{Ba}$ \\
\hline
\end{tabular}

Means values followed by the same letter are not significantly different (Tuckey test, $\alpha=5 \%$ ). Capital letters compare the mean values of the substrate $\left(\mathrm{S}_{1}\right.$ and $\left.\mathrm{S}_{2}\right)$ for each bulk density value. Small letters compare the mean values of the bulk densities $\left(\mathrm{D}, \mathrm{D}_{1}, \mathrm{D}_{2}\right.$, and $\left.\mathrm{D}_{3}\right)$ for each substrate. 
In spite of those TP, AS, EAW, and BW values considered as ideals by De Boodt \& Verdonck (1972), the use of a substrate with specific air/water relationship, should be done taking into account the plant species, since plants have different demands of air and water. Ordinarily, substrates are recommended for a group of plants. However, the recommendation should be done taking into account the best air/water relationship for a specific specie (Bugbee \& Frink, 1986). It is difficult to recommend the best substrate for groups of plants because growers use different irrigation techniques, fertilizers, water quality, and switch growth techniques very often. Therefore, the recommendation of a substrate must take

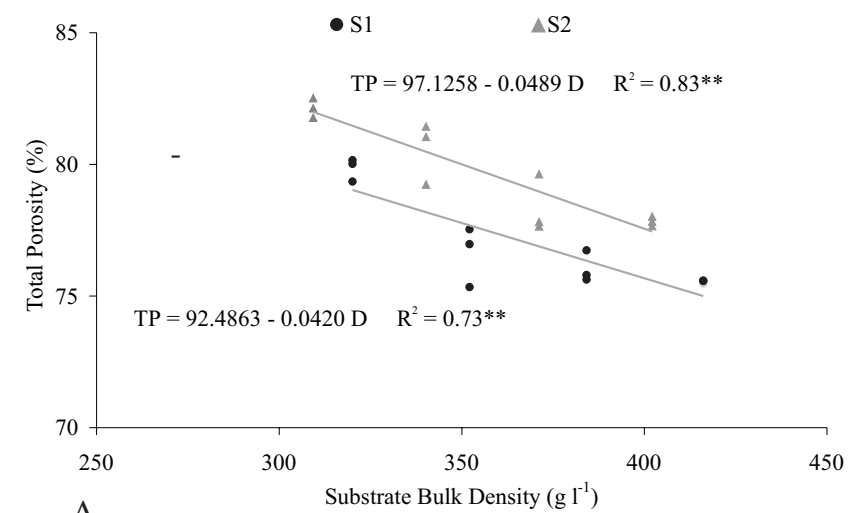

A

Substrate Bulk Density $\left(\mathrm{g}^{-1}\right)$
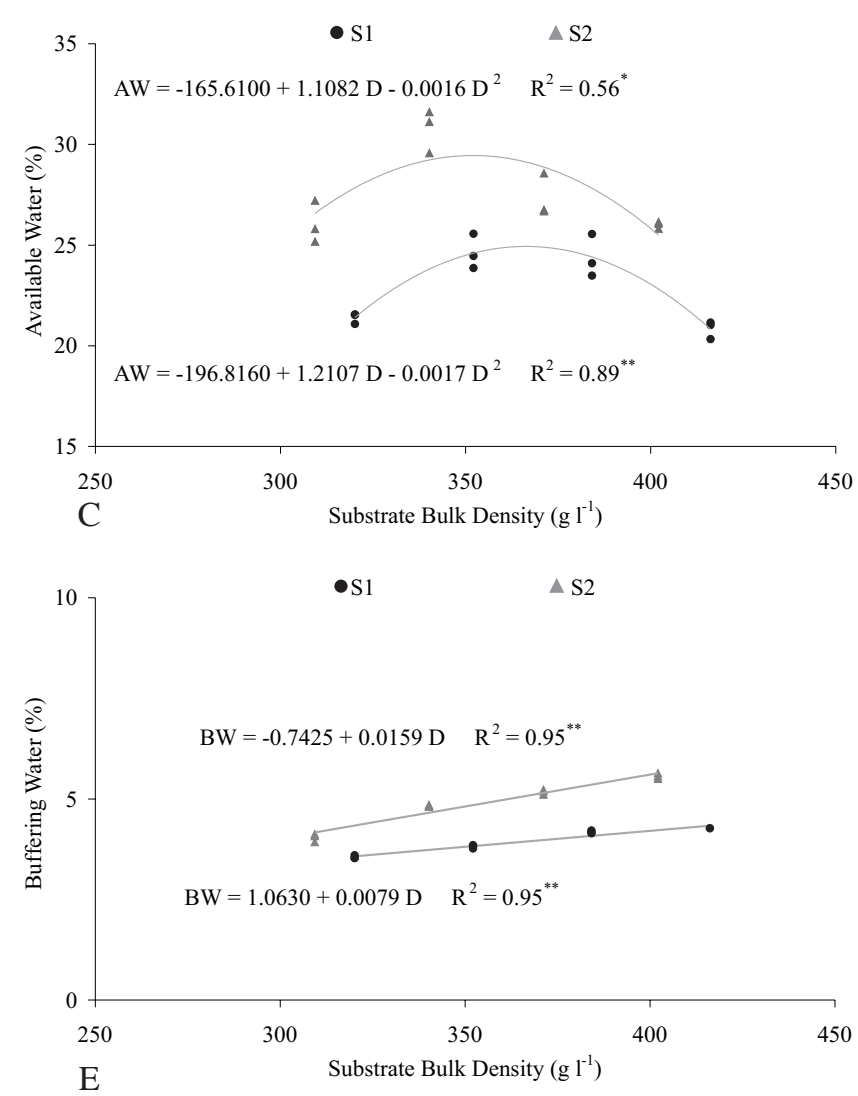

into account the grower conditions instead of a group of species (Verdonck \& Gabriëls, 1988).

As a result of differences among the values of TP, AS, AW, EAW, BW, and RW (Table 2), the mathematical function were fitted for each substrate (Figure $3)$. Then, the functions were used to simulate practical situations, aiming to help growers to select the best substrate bulk density values for specific growth conditions, i. e., for a substrate similar to those used in the present work. The functions were used to obtain the bulk density values (D) for two AS values (10\% and 15\%). Afterwards, by using the D values, the TP and EAW were calculated (Table 3).
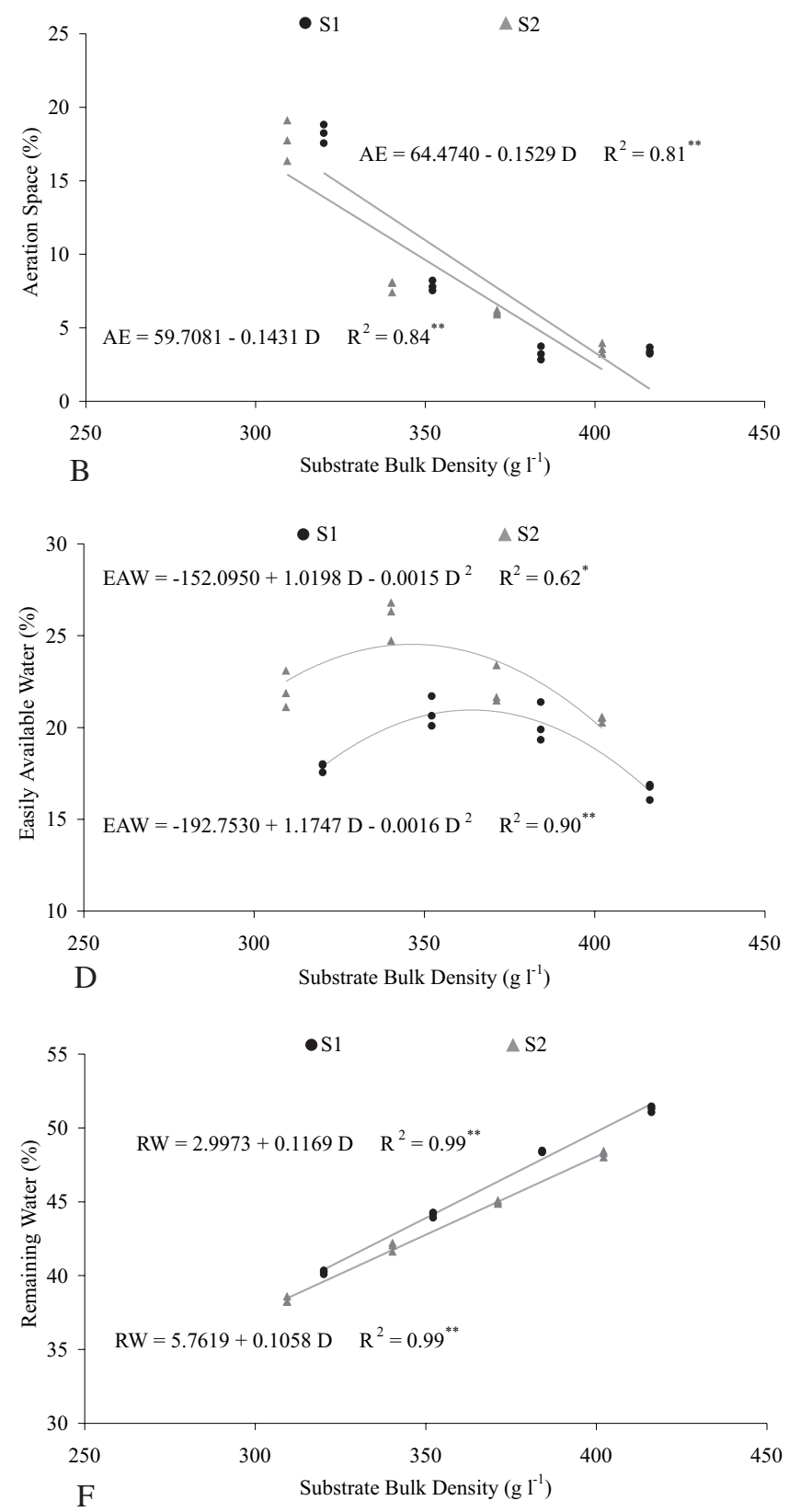

Figure 3 - Fitted curves, regression equations, and determination coefficients $\left(\mathrm{R}^{2}\right)$ for the substrate bulk density, and the following variables: total porosity (a), aeration space (b), available water (c), easily available water (d), buffering water (e), and remaining water (f), for the substrate $S_{1}$ and $S_{2}$.

Sci. Agric. (Piracicaba, Braz.), v.61, n.4, p.446-450, July/August 2004 
Table 3 - Values of bulk density (D), total porosity (TP), and easily available water (EAW), obtained by the regression equations, corresponding to two values of aeration space (AS), for the substrate $\mathrm{S}_{1}$ and $\mathrm{S}_{2}$.

\begin{tabular}{|c|c|c|c|c|c|c|}
\hline \multirow{2}{*}{ AS } & \multicolumn{3}{|c|}{$\mathrm{S}_{1}$} & \multicolumn{3}{|c|}{$\mathrm{S}_{2}$} \\
\hline & $\mathrm{D}$ & $\mathrm{TP}$ & EAW & D & $\mathrm{TP}$ & EAW \\
\hline$\%$ & $\mathrm{~g} \mathrm{~L}^{-1}$ & -..- o/ & $-\ldots$ & $\mathrm{g} \mathrm{L}^{-1}$ & - $\%$ & ---- \\
\hline 10 & 356.3 & 77.5 & 22.7 & 347.4 & 80.1 & 21.2 \\
\hline 15 & 323.6 & 78.9 & 19.8 & 312.4 & 81.8 & 20.1 \\
\hline
\end{tabular}

For $15 \%$ of AS value, the $S_{2}$ showed EAW values in the ideal range (20-30\%), and TP value close to it ( $\pm 85 \%$ ), but showed a bulk density value $4 \%$ higher than the bulk density considerable as ideal $\left(300 \mathrm{~g} \mathrm{~L}^{-1}\right)$. For $10 \%$ of AS value, the $S_{1}$, also, showed EAW value in the ideal range, showing the bulk density value 19\% higher than the one considered ideal, and TP value lower than that considered ideal, i. e. $\pm 85 \%$. The value of the substrate bulk density is not always the limiting condition for a good plant growth.

If the crop does not require a high aeration space, it is possible to increase the substrate bulk density value to get a higher easily available water to the plants. The mathematical models for the substrates $\mathrm{S}_{1}$ and $\mathrm{S}_{2}$ can be used to simulate best air/water relationship to a specific specie before filling the containers. The models can help growers to choose appropriate bulk density of the substrate taking into account the plant species and growth techniques.

\section{REFERENCES}

ANSORENA, J.M. Sustratos: propiedades y caracterizacion. Madri: MundiPrensa, 1994. 172p.

BELLÉ, S. Uso da turfa "Lagoa dos Patos" (Viamão/RS) como substrato hortícola. Porto Alegre: UFRGS/Faculdade de Agronomia, 1990. 143p. (Dissertação - Mestrado).

BUGBEE, G.J.; FRINK, C.R. Aeration of potting media and plant growth. Soil Science, v.141, p.438-441, 1986.

De BOODT, M.; VERDONCK, O. The physical properties of the substrates in horticulture. Acta Horticulturae, n.26, p.37-44, 1972.

FONTENO, W.C.; CASSEL, D.K.; LARSON, R.A. Physical properties of three container media and their effect on Poinsettia growth. Journal of the American Society for Horticultural Science, v.106, p.736-741, 1981.

GÜNTHER, J. Analytics of substrates and problems by transmitting the results into horticultural practice. Acta Horticulturae, n.150, p.33-40, 1983.

KÄMPF, A.N. Produção comercial de plantas ornamentais. Guaíba: Agropecuária, 2000. 254p.

KÄMPF, A.N.; HAMMER, P.A.; KIRK, T. Effect of the packing density on the mechanical impedance of root media. Acta Horticulturae, n.481, p.689-691, 1999.

SPOMER, L.A. Three simple demonstrations of the physical effects of soil amendment. HortScience, v.14, p.75-77, 1979.

VERDONCK, O.; GABRIËLS, R. Substrate requirements for plants. Acta Horticulturae, n.221, p.19-23, 1988.

Received May 05, 2003

Accepted May 14, 2004 